\title{
Partisies van versamelings in metriese en normeerde ruimtes geïnduseer deur konsentriese sfere en ewewydige hipervlakke
}

\author{
K.J. Swanepoel \\ Departement Wiskunde en Toegepaste Wiskunde, Universiteit van Pretoria, Pretoria 0002
}

Ontvang 5 ilaurt 1999; aanvaar 16 Augustus 1999

\section{UITTREKSEL}

'n (Jordekking van 'n versameling $A$ in 'n metriese rumte (M. d) deur eindig veel verskillende konsentriese sfere 'induseer ' $n$ partisie op A. In hierdie artikel word aangetoon dat die kardinaliteit van die versameling van sulke partisies van A nie groter as die digtheid van $M$ (die kleinste kardinaliteit van 'n digte deelversameling van $M$ ) is nie. Hierdie bogrens is skerp vir vele interessante metriese rumtes, soos die $l_{p}(\kappa)$-ruimtes bestaande uit funksies $x: \kappa \rightarrow R$ waarvoor $\Sigma_{\alpha \varepsilon \kappa}|x(\alpha)|^{p}<\infty$

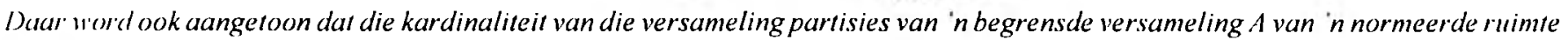
I' geinduseer deur oordekkings van A deur eindig veel ewe wydige geslote hipervlakke nie groter is as die digtheid van die duaal van $X$ in die norm-lopologie nie. Die $l_{p}(\kappa)$-ruimtes voorsien weer voorbeelde waar gelykheid mag geld.

\section{ABSTRACT}

Partitions of sets in metric and normed spaces induced by concentric spheres and parallel hyperplanes.

A covering of a set $A$ in a metric space $(M$, d) by finitely many distinct concentric spheres induces a partition on $A$. In this paper it is: shown that the cardinality of the set of such partitions of $A$ is not greater than the density of $M$ (the least cardinality of a dense subset of $M$ ). This bound is sharp for many interesting metric spaces, such as the $I_{p}(\kappa)$ spaces consisting of fiunctions $x: \kappa \rightarrow R$ for 1 hich $\Sigma_{\alpha \varepsilon \kappa}|x(\alpha)|^{\prime \prime}<\infty$

It is also shown that the cardinality of the set of partitions of a bounded subset $A$ of a normed space $X$ induced by coverings of $A$ by finitely many distinct parallel closed hyperplanes is not greater than the density of the dual of $X$ in the norm topology. The $I_{p}(\kappa)-s p a c e s$ again provide examples where equality may hold.

\section{INLEIDING}

Die volgende oneindige kombinatoriese telprobleem word beskou in die konteks van oordekkings van versamelings in metriese en normeerde ruimtes:

Probleemstelling Bepaal bogrense vir die aantal oordekkings van 'n versameling in in metriese ruimte (normeerde nuimte. respektiew'elik) deur eindig veel konsentriese sfere (ewewydige hipervlakke, respektiewelik)

Hierdie probleem het sy oorsprong in 'n poging om versamelings in (oneindig-dimensionele) Euklidiese ruimtes te verstaan wat eindig $k$-sferies maar nie $k$-sferies is nie, d.w.s. elke eindige deelversameling is bevat in die vereniging van $k$ verskillende konsentriese sfere, maar dieselfde geld nie vir die hele versameling nie.

In hierdie artikel word die probleemstelling beantwoord deur skerp bogrense te bepaal wat verrassend laag is (sien Stellings A en B lieronder).

Eindig $k$-sferiese versamelings duik op in die Euklidiese Ramsey-teorie: Die sogenaamde $k$-Ramsey versamelings in oneindigdimensionele Euklidiese ruimtes het hierdie eienskap ${ }^{1,2.3}$. Eindig hipervlakkige versamelings is ' $n$ interessante variasie daarop, veral in die lig daarvan dat Stelling B (hieronder) net bewys kon word vir begrensde versamelings. Dit is ' $n$ oop vraag of begrensdheid nodig is as hipotese. Dit blyk of eindig hipervlakkige versamelings nie voorheen bestudeer is nie.

Die volgende notasie word gebruik. Dui die kardinaliteit van 'n versameling $A$ aan met \#A. Met 'n partisie $\pi$ van 'n versameling $A$ word bedoel 'n klas nie-leë paargewys disjunkte deelversamelings van $A$ wat $A$ oordek. Die versamelings in 'n partisie $\pi$ word die $b l o k k e$ $\operatorname{van} \pi$ genoem.

Met $T$ word 'n topologiese ruimte aangedui, met $M$ 'n metriese ruimte met metriek $d(\cdot ;)$, en met.$X$ 'n (reèle) normeerde ruimte met norm $\|$. $\|$. Die basiese feite oor sulke ruimtes ${ }^{4.5}$ word gebruik. Die (kontinue) duaal van $X$ (met die normtopologie) word aangedui met $I^{*}$. Die digtheid $d(T)$ van 'n topologiese ruimte $T$ is die kleinste kardinaliteit van 'n digte deelversameling van $T$. Die gewig $w(T)$ van $T$ is die kleinste kardinaliteit van 'n oop basis vir die topologie van $T$. Dit is welbekend dat as $S$ 'n deelruimte van $T$ is, dan geld $w(S) \leq$ $w \%$, en vir metriese ruimtes geld $d(M)=w(M)$. Die sfeer met middelpunt $m \in M$ en straal $r \geq 0$ is die versameling $\Sigma(n, r)=\{x \in$ $|/| d(x, m)=r$. ' $n$ Eindige partisie $\pi$ met blokke $B_{1}, B_{2}, \ldots, B_{k}$ van $A \subseteq M$ is eindig sferies as daar $m \in M$ en $r_{1}, \ldots, r_{k} \geq 0$ bestaan só dat $B_{i} \subseteq \sum\left(m . r_{i}\right)$ vir elke $\iota=1, \ldots . k$.'n Eindige partisie $\pi$ van 'n deelversameling $A$ van 'n normeerde ruimte $X$ is eindig hipervlakkig as daar ' $n$ geslote hipervlak $H$ van $X$ en $v_{1}, \ldots, v_{k} \in X$ bestaan só dat $B_{i} \subseteq v_{i}+H$ vir elke $i=1, \ldots k$

Stelling A l'ir enige deelversameling $A$ van n metriese ruimte $M$ geld

$\#\{\pi \mid \pi$ is $n$ eindig sferiese partisie van $A\} \leq d(M)$.

Hierdie ongelykheid is ' $n$ verskerping van die triviale bogrens $\# M$. 'n Soortgelyke opmerking geld vir die volgende stelling. 
Stelling B Fir enige begrensde deelversameling $A$ van 'n normeerde ruimte $X$ geld

$$
\#\{\pi \mid \pi \text { is 'n eindig hipervlakkige partisie van } A\} \leq d\left(X^{*}\right) \text {. }
$$

In die volgende afdeling word 'n algemene resultaat bewys (Stelling C) waarvan Stellings A en B gevolge is. Ook word voorbeelde gegee wat aantoon dat die ongelykhede in Stellings A en B skerp is vir ' $n$ interessante klas normeerde ruimtes.

\section{DIE TEL VAN TOPOLOGIES GEDEFINIEERDE PARTISIES}

Laat $C_{b}(T)$ die Banachruimte van reëlwaardige kontinue begrensde funksies op 'n topologiese ruimte $T$ wees met norm $\|f\|_{\infty}=$ sup $_{\mathrm{r} \in T} f(x) \mid, f \in \mathbf{C}_{b}(T)$. Die funksie $f \in \mathbf{C}_{b}(T)$ word eindig genoem as $f(T)$ 'n eindige versameling is. Die partisie van $T$ geinduseer deur in eindige $f \in \mathrm{C}_{b}(T)$ is $\pi_{f}=\left\{f^{-1}(r) \mid r \in f(T)\right\}$.

Die volgende stelling gee 'n bogrens vir die kardinaliteit van die versameling van partisies geïnduseer deur eindige funksies:

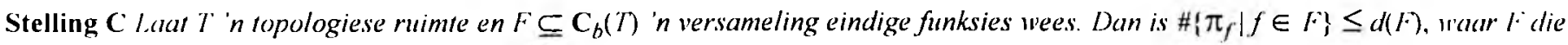
deelruimretopologie het geinduseer deur $\mathrm{C}_{b}(T)$.

Bewys Laat $l^{\prime}=\left\{\pi_{f} \mid f \in F\right\}$. Aangesien die stelling triviaal is as $F$ 'n eindige versameling is, mag aangeneem word dat $F$ en $l^{\prime}$ oneindig is. Kies vir elke $\pi \in P^{\prime} n f \in F$ só dat $\pi=\pi_{f}$. Laat die versameling funksies só gekies (' wees. Dan geld \#C $=\# P$, en daar moet dus aangetoon word dat $\# C \leq d(F)$.

Kies 'n digte deelversameling $D$ van $C$ ' só dat $\# D=d(C)$. Omdat $C$ oneindig is, sal $D$ ook oneindig wees. Ken die produktopologie toe aan die kartesiese produk $\mathbf{R}^{D}$, en laat $p_{f}: \mathbf{R}^{D} \rightarrow \mathbf{R}$ die kanoniese projeksie wees vir elke $f \in D$. Definieer $\Phi: T \rightarrow \mathbf{R}^{D}$ deur $p_{f}$ o $\Phi$ $=f$. Dan is

$\Phi\left(h \subseteq \prod_{(r: l)} f(T) \subseteq \mathbf{R}^{D}\right.$

Aangesien elke $f(T)$ eindig is, is $\prod_{f \in D} f(T)$ 'n kompakte versameling in $\mathbf{R}^{D}$ uit Tychonoff se stelling, en dus geslote in $\mathbf{R}^{D}$. Dit volg dat $S=\overline{\Phi(T)}$ (die afsluiting van $\Phi(7)$ in $\mathbf{R}^{D}$ ) kompak is. Beskou nou elke $p_{f}$ as beperk tot $S$, en beskou ook $\Phi: T \rightarrow S$. Die volgende kommutatiewe diagram word nou verkry.

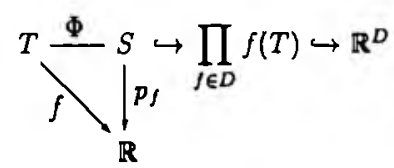

Duidelik kan elke $f \in D$ deur $\Phi$ gefaktoriseer word, d.w.s. $f=p_{f} \circ \Phi$. Nou word aangetoon dat elke $f \in C$ deur $\Phi$ gefaktoriseer kan word. d.w.s. vir elke $f \in\left(\right.$ ' bestaan daar'n kontinue $q_{f}: S \rightarrow \mathbf{R}$ sodat $f=q_{f} \circ \Phi$.

Beskou die funksie $L: \mathbf{C}_{b}(S) \rightarrow \mathbf{C}_{b}(T) ; g \mapsto$ go $\Phi$. Duidelik is $L$ 'n lineêre operator. Ook is $L$ 'n isometrie. d.w.s. $\|L g\|_{\infty}=\|g\|_{\infty}$ vir alle $g \in C_{b}(S)$. Inderdaad, aangesien $\Phi(T)$ dig is in $S$, volg dat

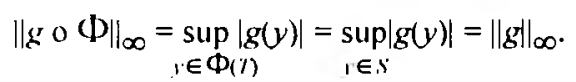

Dit volg dat $L\left(\mathbf{C}_{b}(S)\right)$ 'n volledige deelruimte van $\mathbf{C}_{b}(T)$ is, en dus geslote is. Aangesien $D \subseteq L\left(\mathbf{C}_{b}(S)\right)$, word $C^{\prime} \subseteq L\left(\mathbf{C}_{b}(S)\right)$ verkry. d.w.s. elke $f \in($ ' kan gefaktoriseer word deur $\Phi$.

Kies vir elke $f \in C^{\prime}$ 'n $q_{f} \in \mathbf{C} b(S)$ só dat $f=q_{f} \circ \Phi$. Dan is $\# C=\#\left\{q_{f} \mid f \in C\right\}$. Ook, vir elke $f \in C^{\prime}$ geld

I. $\quad 4(S)=f(7)$

2. $\pi_{f}=\left\{\Phi^{-1}(A) \mid A=q_{f}^{-1}(r)\right.$ vir'n $\left.r \in q_{f}(S)\right\}$,

3. elke $q_{1}{ }^{1}(r)$, waar $r \in q(S)$, is 'n geslote en oop deelversameling van $S$.

Daar is dus 'n injeksie $C \rightarrow \kappa ; f \mapsto\left\{q_{f}^{-1}(r) \mid r \in f(T)\right\}$, waar $K$ die klas van eindige versamelings van geslote oop deelversamelings van $S$ is.

Nou word aangetoon dat $\# K \leq \# D$. Die topologie van $\prod_{f \in D} f(T)$ het 'n oop basis van kardinaliteit \#D. en aangesien $S$ ' $n$ deelruimte is, is $w(S) \leq \# D$. Enige geslote oop deelversameling $S$ is beide kompak en 'n vereniging van basiese oop versamelings. en is dus " 1 eindige vereniging van basiese oop versamelings. Dus het $S$ hoogstens $\# D$ geslote oop deelversamelings. waaruit $\# K^{\prime} \leq \# D$ volg.

Dus geld $\#\left({ }^{\prime} \leq \# K \leq \# D=d(C) \leq d(F)\right.$ (die laaste ongelykheid volg omdat $F$ 'n metriese ruimte is).

Q.E.D. 


\section{BEWYS VAN STELLING A}

Definieer $f_{m}: A \rightarrow \mathbf{R} ; a \mapsto d(m, a)$ vir elke $m \in M$. As

$r=\left\{f_{m} \mid m \in, /\right.$ en $f_{m}$ is eindig $\}$,

dan is $l \subseteq C_{h}(A)$ en volg

$\#\{\pi \mid \pi$ is 'n cindig sferiese partisie van $A\}=\#\left\{\pi_{f} \mid f \in F\right\} \leq d(F)$

uit Stelling (

Laat $. I^{\prime}=\left\{m \in M \mid f_{m} \in F\right\}$. Die afbeelding $\psi: M^{\prime} \rightarrow F ; m \rightarrow f_{m}$ is kontinu: Vir enige $m . m^{\prime} \in W^{\prime}$ geld

$$
\left\|f_{m}-f_{m, m^{\prime}}\right\|_{\infty}=\sup _{u \in \lambda}\left|d(m, a)-d\left(m^{\prime}, a\right)\right| \leq d\left(m, m^{\prime}\right)
$$

As 'n digte deelversameling $D$ van $M^{\prime}$ ' gekies word só dat $\# D=d\left(M^{\prime}\right)$, dan is $\psi(D)$ dig in $\psi\left(M^{\prime}\right)=F$, en dus is $d(F) \leq \# \psi(D) \leq \# D$. Q.E.D

Nou word aangetoon dat gelykheid wel moontlik is in Stelling A vir $M=l_{p}(\kappa)$ waar $\kappa$ 'n oneindige kardinaal is en $1 \leq p \leq \infty$. As 1 $\leq_{p}<\infty$, word $l_{p}(\kappa)$ gedefinieer as die ruimte van funksies $x: \kappa \rightarrow \mathbf{R}$ só dat $\sum_{\alpha \in \kappa}|x(\alpha)|^{p}<\infty$ met norm $\|x\|_{p}=\left(\sum_{\alpha \in \kappa} \mid x(\alpha) ?^{\prime \prime}\right)^{1 / p}$. Ook word $l,(\kappa)$ gedefinieer as die ruimte van funksies $x: \kappa \rightarrow \mathbf{R}$ so dat $\sup _{\alpha \in \kappa}|x(\alpha)|<\infty$ met norm $\|x\|_{\infty}=\sup _{\alpha \in \kappa}|x(\alpha)|$. Let op dat $d\left(I_{p}(\kappa)\right)=\kappa$ vir $I \leq p<\infty$ en $d\left(I_{\infty}(\kappa)\right)=2^{\kappa}$.

Definieer $e_{\beta}: \kappa \rightarrow \mathbf{R}$ vir elke $\beta \in \kappa$ deur $e_{\beta}(\alpha)=1$ as $\alpha=\beta$ en $e_{\beta}(\alpha)=0$ as $\alpha \neq \beta$. Dan is $B=\left\{e_{\alpha} \mid \alpha \in \kappa\right\}$ bevat in elke $l_{p}(\kappa)$. $l \leq p \leq \infty$. As $1 \leq p<\infty$, dan vir elke eindige nie-leë $S \subseteq B$ is die partisie $\pi=\{S, B \backslash S\}$ eindig sferies: Laat $m=\sum_{x \in S^{x}}$ Dan $S \subseteq \sum(m,(\# S-$ $\left.1)^{1 / p}\right)$ en $B \backslash S \subseteq \sum\left(m,(\# S+1)^{1 / p}\right)$. Dus is $\pi_{s}(B) \geq \kappa=d\left(l_{p}(\kappa)\right)$.

As $p=\infty$, dan vir elke $S \subseteq B, S \neq \emptyset, S \neq B$ is die partisie $\pi=\{S, B \backslash S\}$ eindig sferies: Definieer $m \in l_{\infty}(\kappa)$ deur $m(\alpha)=1$ as $\iota_{\alpha}$ $\in S$ en $m(\alpha)=-1$ andersins. Dan $S \subseteq \sum(m, 1)$ en $B \backslash S \subseteq \sum(m, 2)$. Dus is $\pi_{s}(B) \geq 2^{\kappa}=d\left(l_{\infty}(\kappa)\right)$.

\section{BEWYS VAN STELLING B}

Beperk elke kontinue lineêre funksionaal $f \in \lambda^{*}$ tot $A$ en dui dit aan met $f_{A}: A \rightarrow \mathbf{R}$. Laat $F=\left\{f_{A} \mid f \in \gamma^{*}\right.$ en $f_{A}$ is eindig . Dan is $f^{*} \subseteq$ $C_{b}(1)$, en is

$\#\{\pi \mid \pi$ is 'n eindig hipervlakkige partisie van $A\}=\#\left\{\pi_{f} \mid f \in F\right\} \leq d(F)$

uit Stelling C.

Aangesien .1 begrens is, is die afbeelding

$\psi:\left\{f \in I^{*} \mid f_{A} \in F\right\} \rightarrow F ; f \mid \mapsto f_{A}$

kontinu: Vir elke $f, f^{\prime} \in X^{*}$ geld

$\left\|f_{A}-f_{A}^{\prime}\right\| x=\sup _{u \in A}\left|\left(f^{\prime}-f^{\prime}\right)(a)\right| \leq\left\|f-f^{\prime}\right\| \sup _{a \in A}\|a\|$.

Die gevolgtrekking $d(F) \leq d\left(A^{*}\right)$ volg nou op dieselfde wyse as in die bewys van Stelling $A$.

Q.E.D

Om aan te toon dat gelykheid moontlik is in Stelling $\mathrm{B}$, word die ruimtes $X=l_{p}(\kappa)$ vir $1 \leq p<\infty$ en die versameling $B=\left\{e_{\alpha} \mid \alpha \in\right.$ $\kappa\}$ gebruik. Dit is welbekend dat $l_{1}(\kappa)^{*}$ isometries is aan $l_{\infty}(\kappa)$, en vir $\mathrm{I}<p<\infty$ is $l_{p}(\kappa)^{*}$ isometries aan $l_{q}(\kappa)$ waar $\frac{1}{p}+\frac{1}{q}=1$. Die ruimtes $l_{1}(\kappa)^{*}$ en $I_{x}(\kappa)$ word op die standaardwyse geïdentifiseer, so ook $I_{p}(\kappa)^{*}$ met $l_{q}(\kappa)$.

As $p=1$ dan vir elke $S \subseteq B, S \neq \emptyset, S \neq B$, word $f \in l_{\infty}(\kappa)$ gedefinieer deur $f(\alpha)=0$ as $e_{\alpha} \in S$. en $f(\alpha)=1$ andersins. Dan is $\{S, \beta$ $\backslash S\}=\left\{f^{-1}(0), f^{-1}(1)\right\}$ 'n eindig hipervlakkige partisie van $B$, en dit volg dat $\pi_{h}(B) \geq 2 \kappa$.

As $1<p<\infty$, word $f \in I_{q}(\kappa)$ op 'n soortgelyke wyse gedefinieer, maar nou slegs vir eindige nie-leë $S \subseteq B$. Dit volg soorgelyk dat $\pi_{h l}(B) \geq \kappa$.

\section{SUMMARY}

The following infinite combinatorial counting problem is considered in the context of coverings of sets in metric and normed spaces.

Problem Statement Determine upper bounds for the number of partitions of a set in a metric space (normed space. respectively) by 
finitely many concentric spheres (parallel hyperplanes, respectively)

This problem arose in a study of so-called $k$-Ramsey sets in Euclidean Ramsey theory ${ }^{1,2.3}$.

In this paper an answer is provided to the problem statement by obtaining sharp upper bounds involving the density of the spaces involved. The density of a metric space $M$, denoted by $d(M)$, is the least cardinality of a dense subset.

The continuous dual of a nomed space $X$ with the norm topology is denoted by $X^{*}$. A finite partition of a subset $A$ of a metric space is finitely spherical if there is a set of concentric spheres such that each block of the partition is contained in one of the spheres. A linite partition of a subset $A$ of a normed space is finitely hyperplanar if there is a closed hyperplane such that each block of the partition is contained in a translate of the hyperplane.

Theorem A For any subset A of a metric space $M$, the cardinality of

$\{\pi \mid \pi$ is a finitely spherical partition of $A\}$

is a most $(1) M$.

Theorem B for any bounded subset $A$ of a normed space $X$, the cardinality of

$\{\pi \mid \pi$ is a finitely hyperplanar partition of $A\}$

is at most d( $\left.\gamma^{*}\right)$.

The above bounds are sharp for many interesting metric spaces, such as the $I_{p}(\kappa)$ spaces consisting of functions $x: \kappa \rightarrow \mathbf{R}$ for which $\sum_{\alpha \in K^{\prime}}|x(\alpha)|^{\prime \prime}<\infty$, where $K$ is an infinite cardinal.

The above two theorems are corollaries of the following theorem on topologically defined partitions. Let $C_{b}(T)$ be the Banach space of continuous bounded functions on a topological space $T$ with norm $|f f|_{\infty}=\sup _{x \in T}\left\{f(x) \mid, f \in \mathbf{C}_{b}(7)\right.$. The function $f \in \mathbf{C}_{b}(T)$ is $f i n i t e$ if $f(T)$ is a finite set. The partition of $T$ induced by a finite $f \in \mathbf{C}_{b}(T)$ is $\pi_{f}=\left\{f^{-1}(r) \mid r \in f(T)\right\}$.

Theorem $\mathrm{C}$ led $T$ be a topological space and $\mathrm{F} \subseteq \mathrm{C}_{b}(T)$ a set of finite functions. Then the curdinality of $\{\pi, f \in F\}$ is at most $d(F)$. where fo has the subspace topology induced by $\mathbf{C}_{b}(T)$.

\section{LITERATUURVERWYSINGS}

I Irdos. P'. (ifaham, R.L., Montgomery, P., Rothschild, B.L., Spencer, J., Straus, E.G. (1973). Euclidean Ramsey Theorems I. J. Comb. Th Ser. A 14. 34 1-363.

2 Erdiss. P.. (iraham, R.L. Montgomery, P., Rothschild, B.L., Spencer, J., Straus, E.G. (1975). Euclidean Ramsey Theorems II, in Infinite and Finte Sets. Ilajnal. A. Raddo, R. Sos, V.T. eds. (North Holtand, Amsterdam) pp. 529-558.

3 Siwanepocl. K.J. (1993). Euclidean Ramsey Theory (M.Sc. Dissertation, University of Pretoria).

4 Munkies. J.R. (1975). Topology, A First Course (Prentice-Ilall, Englewood Cliffs, New Jersey).

5 Reed. M.. Simon. B. (1980). Functional Analysis, Methods of Modern Mathematical Physics, Vol. I (Academic Press, San Diego)

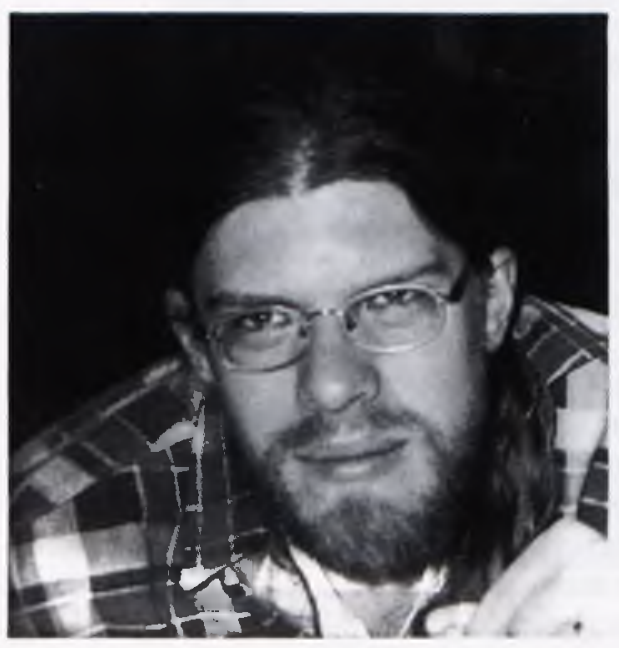

Konrad Swanepoel is 'n senior lektor in die Departement Wiskunde en Toegepaste Wiskunde aan die Universiteit van Pretoria. waar hy ooksy Ph. D graad in Wiskunde verwerf het. Hy spesialiseer in Konvekse en Diskrete Meetkunde en die toepassings daarvan. en is die outeur van sewe spesialisartikels in hierdie gebied. Hy het 'n kursus op derdejaarvlak onmikkel in die Aksiomariek van Elementere Meerkunde. wat by die Liniversiteit ran Pretoria aangebied word. In sy vrye tyd bestudeer hy Star Trek en die musiek van Philip Glass. 